\title{
Technical and Vocational Education and Training in the UAE
}

\author{
https://doi.org/10.3991/ijet.v15i13.13801
}

\author{
Amjad K. Owais $\left.{ }^{(}\right)$, Suzan Mahmoud Alabidi, \\ Al Ain University, Abu Dhabi, UAE \\ amjad.owais@aau.ac.ae \\ Zaydoon Mohammad Hatamleh \\ Al Ain University, Abu Dhabi, UAE \\ Universiti Teknologi Malaysia (UTM), SKUDAI, Malaysia
}

Elham T. Hussein

Al Ain University, Abu Dhabi, UAE

\begin{abstract}
This study is of three-fold. The first provides a general overview of the history and importance of "Technical and Vocational Education and Training" (TVET); the second compares TVET in The United Arab Emirates (UAE) and the United Kingdom (as a pioneer country in the field) in order to explore points of similarity and differences and to make recommendations for TVET improvement in UAE; and the third analyses the relationship between teacher training programmes, accessibility to technical resources, teachers' technology integration, and the mission and vision of technical and vocational institutes in UAE. Data were collected from 175 teachers and administrators of Technical Vocational Colleges (TVCs) in the UAE. To ensure a comprehensive exploration of the topic, three separate research models were developed and tested. All models were analysed using covariance-based structural equation modelling (SEM) through AMOS version 24. Results showed that there is a positive and significant relationship between teachers' technology integration, teacher training programmes and accessibility to technical resources/equipment, and the mission and vision of the technical and vocational institutes.
\end{abstract}

Keywords-Technical and Vocational Education and Training, TVET, Integration of Technology, Curriculum Development, UAE, UK Introduction.

\section{Introduction}

The term "Technical and Vocational Education and Training" (henceforth TVET) was officiated at the World Congress on TVET in 1999 [1]. TVET is part of a lifelong learning and training process, which typically starts during secondary school and could continue through tertiary levels. TVET aims at preparing the young graduates for work by providing them with the necessary work-based learning experience, technical skills and theoretical knowledge which are attuned to the job market as well as 
to the national and local context [2] . As the term "Technical and Vocational Education and Training" indicates, TVET has four equally important components: technical, vocational, educational and practical (training). These components do not function in isolation from but in relation to each other. The following definition for technical education, for example, includes the four aspects: technical education is "the academic and vocational preparation of students for jobs involving applied science and modern technology" [3].

This education is often non-academic, career oriented, and commonly referred to as manual or practical activity associated with a particular profession or trade. Therefore, vocational education can be categorized as technical or career education. The integration of technology is important to almost all professions, and the use of technology in education offers important opportunities for both students and teachers to enhance their learning skills through an effective use of multimedia and interactive course designs. Therefore, learning to work with technology is helpful in preparing students to carry out all kinds of tasks efficiently and with greater ease. Today's educational technology is considered the building block that enhances the effects of vocational education [4]. The integration of technology in vocational education has opened up new ways of learning by offering access to the global world market. It has also encouraged teachers to plan and implement a tailored learning environment to highlight learning activities for vocational students [ $\underline{5}$ ].

Vocational education enables students to acquire new skills that are helpful to their career development [6]. This type of education is typically non-academic, career oriented, and commonly thought of as a manual or a set of practical activities associated with a particular profession or trade. Therefore, vocational education can be categorized as technical or career-related education. The significance of vocational education is recognized worldwide especially since the integration of technology in the educational field has resulted in some noteworthy benefits and advances [7].

Instructors in vocational programmes play a vital role in guiding students and equipping them with the necessary knowledge and skills. Accordingly, they significantly impact the process and degree of technology integration in the classroom [8]. In addition, the perception instructors hold towards technology plays a significant role in the degree of success of technology integration. Indeed, among the instructorrelated factors which affect the process of ICT integration in education, instructors' beliefs and attitudes are considered the most significant [9-11] .

Ensuring proper, efficient and smart use of technology in the educational process should be a priority for vocational instructors as this will better enable students to acquire the necessary knowledge and skills to efficiently use technological tools in their professions[12]. In order to integrate technical and vocational programmes into society, vocational instructors should not only believe in the importance of such integration, but also have the skill and competence to use and apply new technologies that constantly influence the way people learn, work, and live. Thus, in order to produce tomorrow's leaders, vocational instructors should embrace and master the everdeveloping technologies.

Since the Information and Communications Technology (ICT) dominates the world of work, technology must be integrated with vocational education and training appli- 
cations should play an essential part [13]. In general, instructors in the educational field are expected to have knowledge of ICT that would enable them to effectively fulfil their duties. Instructors' attitude towards technology is an important factor in adopting and integrating various types of ICT into teaching and if they are to become effective training leaders, they should employ advanced approaches to deliver these skills to their students[14]. Due to the evolving nature of the global workplace, urgent measures are required to meet the growing need for vocational education.

The main purpose of vocational education is to prepare students for their professional careers by providing them with the knowledge and skills that are necessary for survival amidst global competition. Students in the vocational and technical setting have opportunities to acquire theoretical and academic knowledge as well as practical skills by learning how knowledge is applied in the real world. Vocational and technical students spend most of their time in integrated classrooms learning through hands-on classes related to their career interests. Contextual learning leading to higher order thinking and problem solving skills is the focus of vocational and technical education[15]. The ability of an individual to solve problems and use higher-order thinking skills in academic and professional settings may help students adapt to the rapidly changing global environment[16].

\section{Literature Review}

Technology affects virtually every aspect of human activity: private and public domains and institutions, economic, educational, medical and social systems, political structures, international affiliations, and the condition of human lives in general[17].

Technology education is about innovation and how people view the world around them and apply technical solutions to find solutions for various types of problems. Technology education has been defined as the prudent application of knowledge and skills such as information and communication technology, materials and structures, operations and manufacturing, food technology strategies and management, systems and control, and technology and living [18]. Fath-Allah [19] defined technology education as a discipline that focuses on teaching technology as a human activity, using control systems and their basic elements such as tools, materials, knowledge, skills, people, power, time, and funding. According to Lillis, Harrington [20], technology education is the type of knowledge that deals with the creation and use of technical means and their interrelation with life, society, and the environment. Williams [21] proposes that technology literacy results from technology education and defines it as "the ability to use technology to access and communicate information effectively, to use a computer and its software to accomplish physical tasks, and to identify the appropriate technology to use in specific situations." Regardless of definition, researchers agree that technology education prepares students for the job market more effectively than traditional education. It is, therefore, surprising that technical training, science, and information technology curricula are not emphasized in many academic programmes [22-24]. 
In order to make decisions in technical fields, it is necessary for students to learn how to effectively assess and evaluate technology and the use of it. Competence for evaluation and assessment occurs within technical operations [25]. In addition to computers, there are other technology-dependent ways for providing students with the learning content. These include mobile devices such as smartphones and tablets [26] and digital games [27] among others.

According to Harter [28], the integration of technology in education enhances both the material that the students learn and the teaching methods that are used to deliver this material. It is important to remember that in our present time teaching and learning no longer take place in closed towers. Instead, an integrated educational experience must be part of a curriculum where the content emphasizes the relation and interconnectedness between the acquisition and creation of knowledge and the quest for meanings and objectives [20]. The learning environment should also guide students to establish the relationship between the in-classroom and out-of-classroom learning, through community-based learning experiences, student associations and organizations, sport and recreational activities, among others [29]. Research has shown that students expect all instructors to integrate technology when teaching, and that they prefer learning core content materials that are supplemented with technology [20].

Foster, Kelley [30] suggests that pre-service teacher education plays a crucial role in developing teachers' ability to align with the way technology is represented in the national curriculum, building on the perception, understanding, and experiences that students bring into the programme. Current educational curricula need to be regularly revised and modified to meet the expectations of today's youth and to boost their interest in learning. To achieve this goal, it is necessary to integrate technology in the educational environments and curricula [31, 32].

It is equally important to educate young students about the wide range of professions TVET can provide. Counter to the traditional belief that TVET caters almost exclusively for students who are academically weak and whose chances to be admitted to universities are limited, TVET should be viewed as an opportunity and a vocational path that provides students with a theoretical framework, workshop-based education and a hands-on experience that enables them to excel in today's global market [33] .

Since the 1700 's, businesses and schools have created partnerships primarily to ensure that graduates possess the theoretical knowledge and the practical experience needed to maximize their exposure to the workplace during school life while simultaneously serving in the community where they might develop future prospects. However, until the end of the 20th century, no formal legislation was developed to encourage such partnerships. In recent times, educational reforms such as the Carl D. Perkins Vocational Technical Education Act of 1998 and its 2006 reauthorization in the US placed extra pressure on school administrations to improve vocational and technical education for students. The Act mandates that schools offer instruction and training that provide students with guidelines for post-secondary education and help them succeed at work [16].

Federal directives in the US failed to bring about the desired results, and numerous scholarly studies have shown that high schools still produce graduates who do not 
possess the necessary skills that would enable them to survive in the work market of the 21st century [34]. In 2004, Achieve [34] Achieve [12] carried out a study to investigate students' opinions on the relevance of the knowledge and skills they receive at school to the workplace. The results of the study showed that $40 \%$ of recent high school graduates think that there is a significant discrepancy between what they were taught at school and the knowledge, skills, and expertise required at the workplace. In the area where the study was conducted, the insufficiency of professional skills which high school graduates have has led to a higher rate of unemployment [35]. At times, finding highly skilled mechanics and auto technicians, for example, is already a difficult task for employers. Furthermore, it is predicted that in the near future there will be greater demand for roles that are significantly dependent on and enhanced by the use of technology [36].

Massachusetts initiated a Commonwealth Readiness Project that proposed an action plan to offer high quality public education to all residents over the next decades. This project helps students find training, internships and jobs opportunities and thus get the chance to apply their theoretical knowledge and sharpen the skills necessary to succeed in the work market [37] . With increasingly challenging opportunities and rewarding salaries, the demographics of TVET students has also changed. In UAE, rigorous academic programmes such as the National Institute for Vocational Education (NIVE) and ADNOC Technical Institute (ATI) have been founded to offer vocational training programmes that help students to grow during college and in the job market.

There are numerous advantages for TVET programmes. Businesses prefer to hire individuals with a specific set of skills needed for a particular profession. Therefore, employability is often viewed as a primary advantage of TVET. Another advantage of TVET systems is the fact that they are typically shorter and more affordable than university programmes. While obtaining a BA or A BSc degree in any discipline typically requires four years in average, a TVET programme could only last for a few months. It is therefore important for the governments of both developed and developing countries to invest in the use of technology and for instructors to learn and teach these 21st century skills to TVET students. Finally, with the increasing demand for TVET competent graduates, salaries have become more attractive.

\section{TVET in the UK and the UAE}

The UK and UAE have very different historical, geographical, economical, demographic and political backgrounds. However, when TVET in both countries is considered, it is possible to find substantial points of convergence. The European AngloSaxon UK came into being in 1922 while the Middle Eastern Arab UAE was established in 1971. With a population of approximately 67 million, the UK is almost seven times that of UAE (which according to the World Bank was 9.6 million in 2019). Also, while UK is a constitutional monarchy that highly depends on manufacturing, industry and services, the UAE is a constitutional federation which economy is diversified but highly oil reliant. Despite these differences, when TVET is considered, it is 
possible to locate numerous points of similarity. The history of TVET system in the UK dates back to the 12th century and has been evolving ever since. The system is regularly reviewed and has recently undergone extensive and substantive reforms in order to ensure that a. the current TVET system is suitable for the country's changing industrial needs, human resource strategy, economic development and future growth, and $b$. the current and future workforce in the UK possess the high-level skills required for succeeding in today's global economy [36].

The TVET in the UK is one of the world's pioneer and most diverse qualification systems. Among the many strengths of the TVET system in the UK are the following: It is demand driven, industry focused and learner centered; it has high impact because of its flexibility and size (it has 26,450 national qualifications, 155 awarding organizations and over 6,500 training entities that annually cater for 3.4 million TVET students); it is a well-integrated system that allows students to move seamlessly between the academic and vocational domains; it offers a world leading model of Degree/Graduate Apprenticeship which enables students to develop advanced skills without the need to go to university; it ensures long term financial sustainability; it is regularly reviewed and modified to ensure its continual fitness; and it is subjected to one of the toughest quality inspection systems in the world. TVET programs in the UK are primarily funded by the government which aims to support young people. Additional funding is received from employers and from commercial activities. To ensure the quality of training and skills provided to learners, all TVET providers must have strong relationships with employers, solid governance with a global perspective, high-quality teaching and assessment by teachers and vocational expertise, a dynamic approach to curriculum design, well-equipped facilities and learner centered support services [38].

UAE, which was formally formed in 1971, is a federation of seven Emirates. The economy of UAE enjoys a high degree of political stability and ranks first among fourteen countries in the Middle East and North Africa region and has an overall score that is significantly higher than the regional and world averages $[\underline{39}, \underline{40}]$. UAE is also known as a business hub and financial centre with excellent infrastructures and a business-friendly environment. Tourism, banking, and foreign trade are the most expanding sectors in the UAE. To encourage further direct foreign investment, UAE has established free trade zones and two of these zones are dedicated to education. Strong ties between the UAE and the UK already exist through a long-standing collaboration between the two countries [41].

Due to its relatively young age, especially in comparison to a country like the UK, the educational system in the country is still expanding at all levels to meet the changing demands of the growing population as well as the local and the global markets. To allow for further economic development outside traditional sectors and to build a knowledge-based economy, the UAE government considers education an utmost priority. The importance of education in enhancing the prosperity and success of people is reflected in the insightful saying of the UAE's first president, Sheikh Zayed Bin Sultan Al Nahyan which states that "the greatest use that can be made of wealth is to invest it in creating generations of educated and trained people. This is also evident from the UAE educational plan for 2017-2021, which aims at increasing the rate of 
the higher-secondary graduation rate from 96.7 to 98 percent. In addition, increasing the number of students who complete the higher-secondary level of education and producing graduates with exceptional technical and vocational skills are of particular importance [42].

The educational sector in UAE was given priority since the country came into being, and the educational system regularly undergoes thorough revisions and modifications. However, it was not until the1980s, when Higher Colleges of Technology were established, that the vocational education sector began to receive proper attention [43]. Though in comparison to the UK, the age, scope and size of TVET in UAE is small, significant work has been carried out to expand, improve and restructure the system in order "to meet the needs of an economy which is diversifying into buoyant sectors such as tourism, construction and real estate" [44]. The number of TVET institutes in UAE has increased significantly. For example, by 2016, there were 73 recognized higher education institutions in the UAE offering 589 accredited tertiary programs [43]. The purpose of these institutes is to produce graduates who will be fit for the job market. Examples of training fields these institutes provide include foreign languages and computer training, engineering, banking and finance among others [45].

The demand for TVET in UAE is increasing. According to [44] in order to achieve a sustainable and diversified knowledge-based economy, the ratio of Emiratis with vocational skills to university graduates should be 10 to 1 (i.e. for every university graduate there has to be ten vocationally trained graduates). The government, therefore, aims to a. increase the number of individuals who possess the relevant skills, including technical and vocational skills, for employment; and b. work on building a national system to ensure a high quality TVET system. Selection of skills to be taught to students is largely done with market needs, and new and emerging technologies, materials and systems in mind. The government also ensures an equal access for both women and men to affordable and quality technical, vocational and tertiary education materials and systems. Examples of TVET offered that are in demand in UAE include hospitality, trade, financial and communication services, English language skills, and capacity building measures linked to reform in education in general [42] .

Future prosperity of UAE highly depends on the production of highly qualified national graduates who possess the necessary vocational skills to meet the demands of the technology-bound markets. To achieve this goal, UAE government has focused on a well-defined set of goals for TVET which includes increasing students' awareness about the market needs for advanced knowledge and skills; developing vocational qualifications for UAE nationals; diversifying parties involved in developing high quality qualifications; and encouraging excellence in the field and rewarding it by, for example, ensuring high employability rates as well as decent salaries for the graduates. The first Emirati federal mandate for the year 2010 announced the establishment of the National Qualifications Authority (NQA) in order to "highlight the need to coordinate, activate and ensure the quality of establishing a national system for vocational education and training in the country, aiming to develop qualifications for nationals to enable them to engage in the working environment easily and smoothly, and to enable them to move and transfer among different career pathways related to the 
qualification." For this endeavor to succeed, the educational, industrial, business and other related sectors must work together to ensure that the educational and practical outcomes of TVET are aligned with the needs of the job market and the ambitious vision of the country [42].

To manage and coordinate the TVET system in UAE, the Vocational Education and Training Awards Council (VETAC) was established under the umbrella of the NQA. VETAC is the authority that vets and approves vocational qualifications, sets learning outcomes, shapes programme structures, and gives approval to new technical and vocational institutes [46]. In 2014, VETAC authorized the Abu Dhabi Centre for Technical and Vocational Education and Training (ACTVET) to develop and award vocational credentials in Abu Dhabi and the northern emirates, and approved KHDA to do the same in Dubai. Through consultation with relevant stakeholders and partners, VETAC is responsible for the following set of duties: [47]

- Building a dynamic, modern, responsive, industry-led and quality assured national TVET system that meets the needs of the job market.

- Developing policies, and creating industry-led advisory councils and committees, which will aid in identifying and developing occupational skills and work performance requirements.

- Accrediting educational and training institutions to offer national qualifications.

- Ensuring that TVET provides the public with information about career prospects

- Improving mechanism and quality assurance procedures of recognizing foreign vocational qualifications.

- Providing assistance to entities involved with laborers' skills assessment.

Although producing a highly qualified national workforce is a high priority for the UAE government, plans to go beyond the boundaries of the national and to enter the international arena have also been implemented. The UAE's National Higher Education Strategy 2030 is aimed at strengthening certification standards, enhancing research outputs, building a framework for qualifications, and developing curriculum more directed towards employment requirements. An efficient internationalization strategy has been adopted by the UAE to excel as a "transnational education hub" at a global level [38]. When comparing 38 educational systems, the British Council ranked the UAE as "highly favourable in terms of regulatory frameworks for student mobility, openness to transnational education, and recognition procedures for foreign degrees". For that reason, the UAE is becoming an attractive place for education for both local and international students. Another reason for the educational attractiveness of the UAE is its diversifying economy that offers employment opportunities to those with skills. Dubai International Academic City and the Dubai Knowledge Village hosted the leading numbers of international educational campuses. Furthermore, there are 24 international university campuses are operating, and the latest campus was the "British University of Birmingham", established in 2018. 


\section{Conceptual Frameworks}

To completely comprehend the study topic, following three separate research models were developed on the basis of extensive literature review.

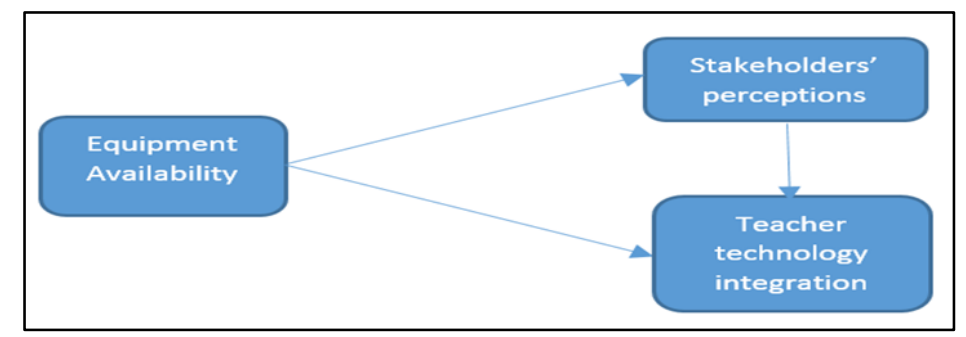

Fig. 1. Model-1 explains the relationship between equipment availability, teacher technology integration, and stakeholders' perceptions.

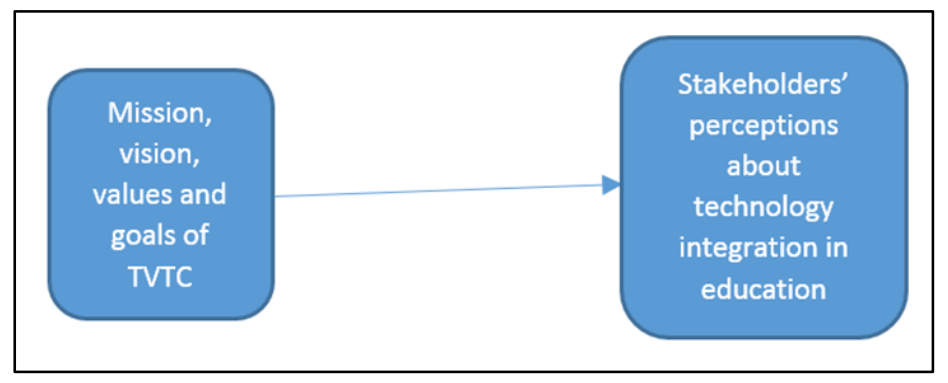

Fig. 2. Model-2 explains the relationship between mission, vision, values, and goals of TVTC, and stakeholders' perceptions about technology integration in education.

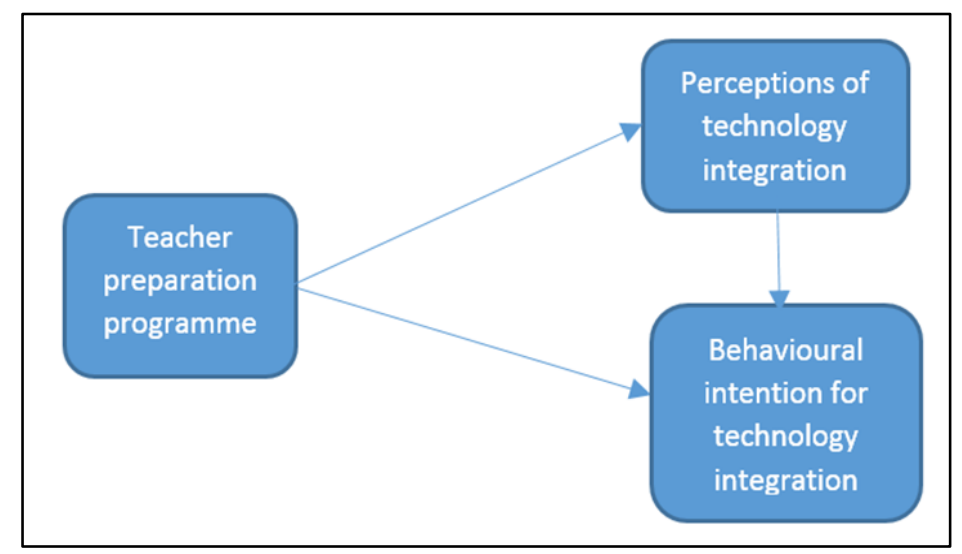

Fig. 3. Model-3 explains the relationship between teacher preparation programmes, perception of technology integration, and behavioural intention for technology integration. 


\section{$5 \quad$ Study Hypotheses}

H1. There is positive direct relationship between equipment availability and stakeholders' perceptions.

H2. There is a positive direct relationship between equipment availability and teacher technology integration.

H3. There is a positive direct relationship between stakeholders' perceptions and teacher technology integration.

H4. Mission, vision, values, and goals of TVTC have a direct and positive influence on stakeholders' perceptions about technology integration in education.

H5. Teacher preparation programmes at university have significant impact on perceptions of technology integration.

H6. Teacher preparation programmes at university have a significant impact on behavioural intentions for technology integration.

\subsection{Methodology}

This part of the study utilized a quantitative research design and the primary data were collected using a structured questionnaire. The sample size of this study was 175 academic professionals and teachers with a background in technical and vocational education. About 250 questionnaires were floated to the target respondents through an online Google form, from which 175 complete responses were received and considered for data analysis. The majority of respondents were males, 153, and the remaining 22 were females. Respondents were highly experienced in technical and vocational education, as $87 \%$ of them had more than seven years of teaching experience. To ensure the privacy of the participants and data confidentiality, the UAE ethical procedures for contacting teachers and administrators and requesting their participation were followed at all times, in accordance with research ethics and the law [48]. An informed consent was also obtained from the participants, who voluntarily participated and were free to withdraw from the study at any time. To ensure a comprehensive investigation of the topic, three separate research models were developed and tested. All models were analysed using covariance-based structural equation modelling (SEM) through AMOS version 24. Reliability and validity of the models were determined by analysing the average variance extracted (AVE), composite reliability (CR), and correlations.

\section{$6 \quad$ Results}

\subsection{Model -1}

Model-1 (see figure 1) explains the relationship between equipment availability, teacher technology integration, and stakeholders' perceptions. This relationship is demonstrated in figure 4, where F1 represents the construct of equipment availability, F2 represents teacher technology integration, and F3 is Stakeholders' perceptions. 
EF1 to EF10 are the items used to measure the construct of equipment availability. Likewise SP1 to SP7 are the items of the construct stakeholder's perceptions and TTI1 to TTI10 are the items to measure teacher technology integration, while e1 to e27 are the error terms to measure the residuals.

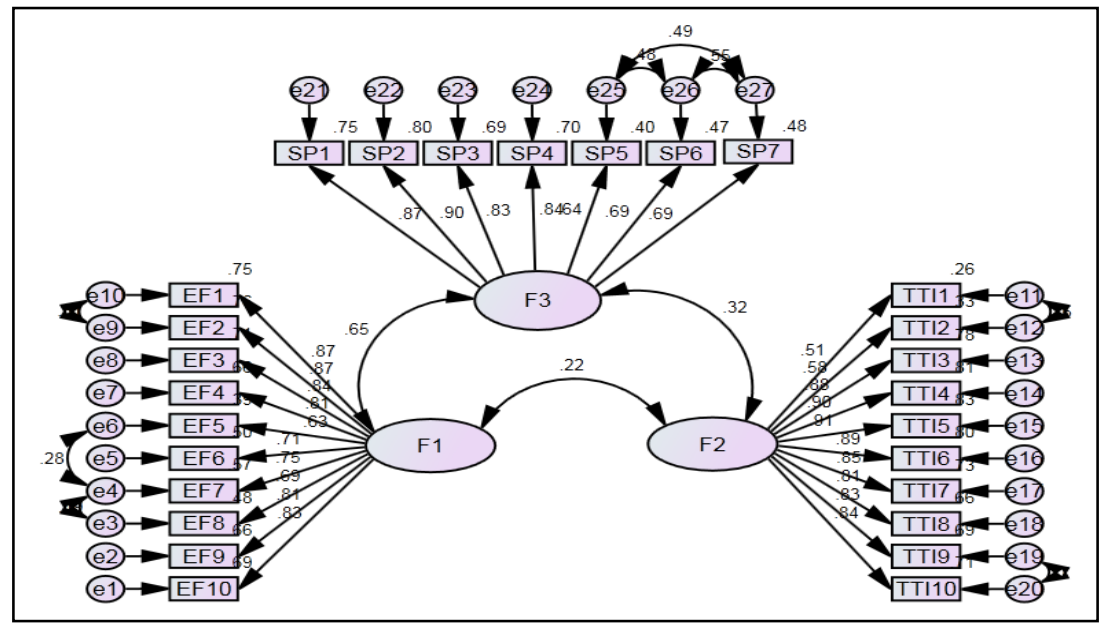

Fig. 4. Model-1 (F1=Equipment availability, $F 2=$ Teacher technology integration, and F3= Stakeholders' perceptions)

\subsection{Validity measures (Model-1)}

Results of validity analysis are presented in table $1 \& 2$. HTMT (heterotraitmontrait ratio of correlations) results show that all values are below 0.850 , which confirms the strict discriminant validity [49]. The values of AVE are also well above the cut-off criteria of 0.50, as recommended by Hu and Bentler [50]. There are also significant correlations among study variables, which confirm that equipment availability, teacher's technology integration, and stakeholders' perceptions have a significant and positive relation to technology integration in technical and vocational education curricula. Composite reliability (CR) results also demonstrate excellent reliability as all the values are well above 0.70 , as suggested by $\mathrm{Hu}$ and Bentler [50].

Table 1. Validity Analysis (model-1)

\begin{tabular}{|l|c|c|c|c|c|}
\hline \multicolumn{1}{|c|}{ Variables (Model-1) } & CR & AVE & $\begin{array}{c}\text { Equipment } \\
\text { availability }\end{array}$ & $\begin{array}{c}\text { Teacher technolo- } \\
\text { gy integration }\end{array}$ & $\begin{array}{c}\text { Stakeholders' } \\
\text { perceptions }\end{array}$ \\
\hline Equipment availability & 0.941 & 0.617 & $\mathbf{0 . 7 8 6}$ & & \\
\hline $\begin{array}{l}\text { Teacher technology inte- } \\
\text { gration }\end{array}$ & 0.950 & 0.661 & $0.219^{*}$ & $\mathbf{0 . 8 1 3}$ & \\
\hline Stakeholders' perceptions & 0.916 & 0.614 & $0.645^{* * *}$ & $0.321^{* * *}$ & $\mathbf{0 . 7 8 3}$ \\
\hline
\end{tabular}

$\mathrm{N}=175$; Significance of Correlations: $\dagger \mathrm{p}<0.100 ;{ }^{*} \mathrm{p}<0.050 ; * * \mathrm{p}<0.010 ; * * * \mathrm{p}<0.001$ 
Table 2. HTMT Analysis (Model-1)

\begin{tabular}{|l|c|c|c|}
\hline \multicolumn{1}{|c|}{ Variables (Model-1) } & $\begin{array}{c}\text { Equipment } \\
\text { availability }\end{array}$ & $\begin{array}{c}\text { Teacher technology } \\
\text { integration }\end{array}$ & $\begin{array}{c}\text { Stakeholders' } \\
\text { perceptions }\end{array}$ \\
\hline Equipment availability & 0.786 & & \\
\hline Teacher technology integration & 0.273 & 0.813 & \\
\hline Stakeholders' perceptions & 0.621 & 0.384 & 0.783 \\
\hline
\end{tabular}

HTMT $=$ heterotrait-monotrait ratio of correlations. $\mathrm{N}=175$

Results of path coefficients are presented in table 3, which show that stakeholders' perceptions and teacher technology integration is significantly predicted by equipment availability $(\beta=0.908, \mathrm{P}<.001 \& \beta=0.167, \mathrm{P}<.05)$. Moreover, stakeholders' perceptions also influence the teacher technology integration $(\beta=0.234, \mathrm{P}<.001)$.

Table 3. Path Coefficients in the Model-1

\begin{tabular}{|l|l|l|c|c|c|}
\hline \multicolumn{2}{|c|}{ Relationships (Model-1) } & Estimate & $\begin{array}{c}\text { S.E } \\
\cdot\end{array}$ & P \\
\hline Equipment availability & $\rightarrow$ & $\begin{array}{l}\text { Stakeholders' percep- } \\
\text { tions }\end{array}$ & .908 & .145 & .000 \\
\hline Equipment availability & $\rightarrow$ & $\begin{array}{l}\text { Teacher technology } \\
\text { integration }\end{array}$ & .167 & .066 & .011 \\
\hline Stakeholders' perceptions & $\rightarrow$ & $\begin{array}{l}\text { Teacher technology } \\
\text { integration }\end{array}$ & .234 & .069 & .000 \\
\hline
\end{tabular}

$\mathrm{N}=175$

Most common fit indices, CMIN/DF (minimum discrepancy divided by its degrees of freedom), RMSEA (Root Mean Squared Error of Approximation), IFI (Incremental fit index), TLI (Tucker Lewis index), and CFI (Comparative fit index), were used to examine the model fitness as recommended by $\mathrm{Hu}$ and Bentler [50]. The results measurement model fitness is presented in table 4 . The values of fit indices for original model-1 shows poor model fit, and by following modification indices excellent model fitness was achieved.

Table 4. Model-1 Fit Summary

\begin{tabular}{|l|c|c|c|c|c|}
\hline \multicolumn{1}{|c|}{ Measurement Models (Model-1) } & $\mathbf{X}^{2} / \mathbf{d f}$ & RMSEA & IFI & TLI & CFI \\
\hline Original Model & 4.593 & .095 & .814 & .802 & .813 \\
\hline Revised Model & 1.396 & .048 & .970 & .966 & .970 \\
\hline Cut-off Criteria (Hu, \& Bentler 1999) & $<3.00$ & $<.08$ & $\geq .95$ & $\geq .95$ & $\geq .95$ \\
\hline
\end{tabular}

\subsection{Model-2}

Model-2 (see figure 2) explains the relationship between mission, vision, values, and goals of TVTC and stakeholders' perceptions about technology integration in 
education. This relationship is presented in figure 5. This relationship was tested by performing confirmatory factor analysis (CFA) through CB-SEM using AMOS-24, and the results are shown in table 8.

Validity and reliability results of model-2 (see figure 5) are presented in table $5 \&$ 6. Composite reliability results in table- 5 demonstrate excellent reliability as all the values are well above 0.70 , as recommended by $\mathrm{Hu}$ and Bentler [50]. HTMT results show that all values below 0.850 confirm the strict discriminant validity [49]. The values of AVE are also well above the cut-off criteria of 0.50 , as suggested by $\mathrm{Hu}$ and Bentler [50]. There are significant correlations among study variables, which confirm that mission, vision, values, and goals of TVTC and Stakeholders' perceptions about technology integration in education have a significant and positive relationship.

Table 5. Validity Analysis (model-2)

\begin{tabular}{|l|l|l|l|l|}
\hline \multicolumn{1}{|c|}{ Variables (Mode-2) } & CR & AVE & $\begin{array}{c}\text { Mission, vision, } \\
\text { values and goals of } \\
\text { TVTC }\end{array}$ & $\begin{array}{c}\text { Stakeholders' perceptions } \\
\text { about technology integration } \\
\text { in education }\end{array}$ \\
\hline $\begin{array}{l}\text { Mission, vision, values } \\
\text { and goals of TVTC }\end{array}$ & 0.840 & 0.514 & $\mathbf{0 . 7 1 7}$ & $\mathbf{0 . 7 7 7}$ \\
\hline $\begin{array}{l}\text { Stakeholders' percep- } \\
\text { tions about technology } \\
\text { integration in education }\end{array}$ & 0.932 & 0.604 & $0.597 * * *$ & \\
\hline
\end{tabular}

Significance of Correlations: $\uparrow \mathrm{p}<0.100 ; * \mathrm{p}<0.050$; ** $\mathrm{p}<0.010$; *** $\mathrm{p}<0.001$; CR $=$ Composite Reliability; AVE= Average Variance Extracted

Table 6. HTMT Analysis (model-2)

\begin{tabular}{|l|c|c|}
\hline \multicolumn{1}{|c|}{ Variables (Model-2) } & $\begin{array}{c}\text { Mission, vision, values } \\
\text { and goals of TVTC }\end{array}$ & $\begin{array}{c}\text { Stakeholders' perceptions } \\
\text { about technology integration } \\
\text { in education }\end{array}$ \\
\hline $\begin{array}{l}\text { Mission, vision, values and goals } \\
\text { of TVTC }\end{array}$ & 0.717 & 0.777 \\
\hline $\begin{array}{l}\text { Stakeholders' perceptions about } \\
\text { technology integration in educa- } \\
\text { tion }\end{array}$ & 0.556 & \\
\hline
\end{tabular}

Results of path coefficients are presented in table 7, which show that Mission, vision, values and goals of TVTC significantly predicts the Stakeholders' perceptions about technology integration in education $(\beta=0.565, \mathrm{P}<.001)$. 
Table 7. Path Coefficients in the Model-2

\begin{tabular}{|c|c|c|c|c|c|}
\hline \multicolumn{3}{|c|}{ Relationships (Model-2) } & Estimate & S.E. & $\mathbf{P}$ \\
\hline $\begin{array}{l}\text { Mission, vision, } \\
\text { values and goals } \\
\text { of TVTC }\end{array}$ & $\longrightarrow$ & $\begin{array}{l}\text { Stakeholders' perceptions } \\
\text { about technology integra- } \\
\text { tion in education }\end{array}$ & .565 & .111 & .000 \\
\hline
\end{tabular}

Table 8. Model-2 Fit Summary

\begin{tabular}{|l|l|l|l|l|l|}
\hline \multicolumn{1}{|c|}{ Measurement Models (Model-2) } & \multicolumn{1}{c|}{$\mathbf{X}^{2} / \mathbf{d f}$} & \multicolumn{1}{c|}{ RMSEA } & \multicolumn{1}{c|}{ IFI } & \multicolumn{1}{c|}{ TLI } & \multicolumn{1}{c|}{ CFI } \\
\hline Original Model & 5.34 & 10 & .784 & .767 & .783 \\
\hline Revised Model & 2.33 & .07 & .958 & .951 & .957 \\
\hline Cut-off Criteria $(\mathrm{Hu}, \&$ Bentler 1999) & $<3.00$ & $<.08$ & $\geq .95$ & $\geq .95$ & $\geq .95$ \\
\hline
\end{tabular}

CFA results show that the initial measurement model indicated poor model fit and all the fit indices were below the required levels. By correlating certain items, excellent model fit was achieved (where $\mathrm{X}^{2} / \mathrm{df}=2.33, \mathrm{RMSEA}=.07, \mathrm{IFI}=.96, \mathrm{TLI}=.95$, $\mathrm{CFI}=.96$ ). Moreover, all the items' loadings were greater than 0.50 , as recommended by $[51]$.

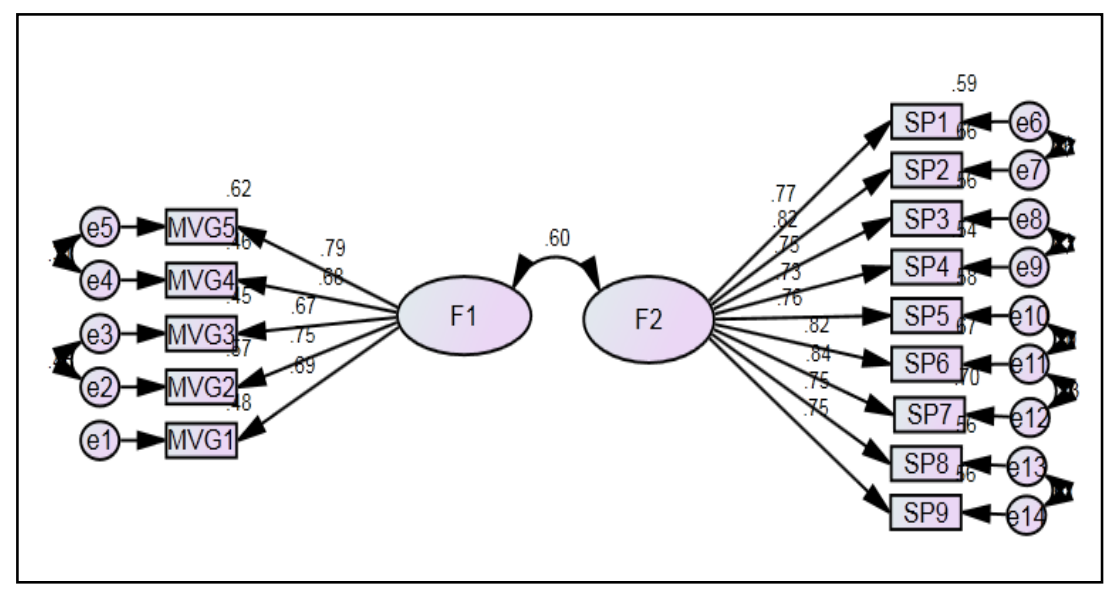

Fig. 5. Model-2 (F1= Mission, vision, values and goals of TVTC, and F2= Stakeholders' perceptions about technology integration in education)

\subsection{Model-3}

Model-3, as shown in figure 3, explains the relationship between teacher preparation programmes, perceptions of technology integration, and behavioural intention for technology integration. This relationship is presented in figure 6 . The quality of model-3 was determined through reliability and validity analysis and the results are shown in tables 9 and 10. Composite reliability (CR) results show excellent construct reliability as all the values are above 0.90 , while the recommended threshold for CR is 0.70 . AVE values are also greater than 0.50 , which confirms the data validity. Moreover, the correlation analyses show there is significant and positive correlation among 
teacher preparation programmes and perceptions of technology integration $(.206, \mathrm{P}<$ $0.05)$, between perceptions of technology integration and behavioural intention for technology integration $(0.323, \mathrm{P}<.001)$, and between behavioural intention for technology integration and teacher preparation programmes $(0.646, \mathrm{P}<.001)$. The HTMT ratio of correlations also confirms excellent discriminant validity as all the values are less than the threshold of 0.85 , as recommended by $\mathrm{Hu}$ and Bentler [50].

Table 9. Validity Analysis (model-3)

\begin{tabular}{|l|c|c|c|c|c|}
\hline Variables (Model-3) & CR & AVE & $\begin{array}{c}\text { Teacher prepara- } \\
\text { tion programmes }\end{array}$ & $\begin{array}{c}\text { Perceptions of } \\
\text { technology } \\
\text { integration }\end{array}$ & $\begin{array}{c}\text { Behavioural } \\
\text { intention for } \\
\text { technology inte- } \\
\text { gration }\end{array}$ \\
\hline $\begin{array}{l}\text { Teacher preparation } \\
\text { programmes }\end{array}$ & 0.916 & 0.734 & 0.857 & 0.809 & \\
\hline $\begin{array}{l}\text { perceptions of tech- } \\
\text { nology integration }\end{array}$ & 0.928 & 0.655 & $0.206^{*}$ & $0.323^{* * *}$ & 0.803 \\
\hline $\begin{array}{l}\text { behavioural inten- } \\
\text { tion for technology } \\
\text { integration }\end{array}$ & 0.915 & 0.645 & $0.646^{* * *}$ & 0.30 & \\
\hline
\end{tabular}

Significance of Correlations: $\uparrow \mathrm{p}<0.100 ; * \mathrm{p}<0.050 ;{ }^{* *} \mathrm{p}<0.010 ; * * \mathrm{p}<0.001 ;$ CR $=$ Composite Reliability; AVE $=$ Average Variance Extracted

Table 10. $\quad$ HTMT Analysis (model-3)

\begin{tabular}{|l|c|c|c|}
\hline Variables (Model-3) & $\begin{array}{c}\text { Teacher preparation } \\
\text { programmes }\end{array}$ & $\begin{array}{c}\text { Perceptions of } \\
\text { technology integra- } \\
\text { tion }\end{array}$ & $\begin{array}{c}\text { Behavioural intention } \\
\text { for technology } \\
\text { integration }\end{array}$ \\
\hline $\begin{array}{l}\text { Teacher preparation } \\
\text { programmes }\end{array}$ & 0.857 & 0.809 & \\
\hline $\begin{array}{l}\text { perceptions of tech- } \\
\text { nology integration }\end{array}$ & 0.265 & 0.390 & 0.803 \\
\hline $\begin{array}{l}\text { behavioural inten- } \\
\text { tion for technology } \\
\text { integration }\end{array}$ & 0.658 & & \\
\hline
\end{tabular}

The cause and effect of teacher preparation programmes on behavioural intention for technology integration and perceptions of technology integration was tested by examining the direct effects through path coefficients. The results are presented in table 11, which show that teacher preparation programmes significantly influence the behavioural intention for technology integration $(\beta=0.736, \mathrm{P}<.001)$ and perceptions of technology integration $(\beta=0.122, \mathrm{P}<0.05)$. Furthermore, the results show signifi- 
cant effect of technology integration's perceptions on teachers' behavioural intention for technology integration $(\beta=0.226, \mathrm{P}<.001)$.

Table 11.

Path Coefficients in the Model-3

\begin{tabular}{|l|c|l|c|c|c|}
\hline \multicolumn{2}{|c|}{ Relationships (Model-3) } & Estimate & S.E. & P \\
\hline $\begin{array}{l}\text { Teacher preparation } \\
\text { programmes }\end{array}$ & $\rightarrow \quad \begin{array}{l}\text { behavioural intention for } \\
\text { technology integration }\end{array}$ & .736 & .122 & .000 \\
\hline $\begin{array}{l}\text { Teacher preparation } \\
\text { programmes }\end{array}$ & $\rightarrow \quad \begin{array}{l}\text { perceptions of technolo- } \\
\text { gy integration }\end{array}$ & .122 & .054 & .023 \\
\hline $\begin{array}{l}\text { Perceptions of technology } \\
\text { integration }\end{array}$ & $\rightarrow$ & $\begin{array}{l}\text { behavioural intention for } \\
\text { technology integration }\end{array}$ & .226 & .068 & .000 \\
\hline
\end{tabular}

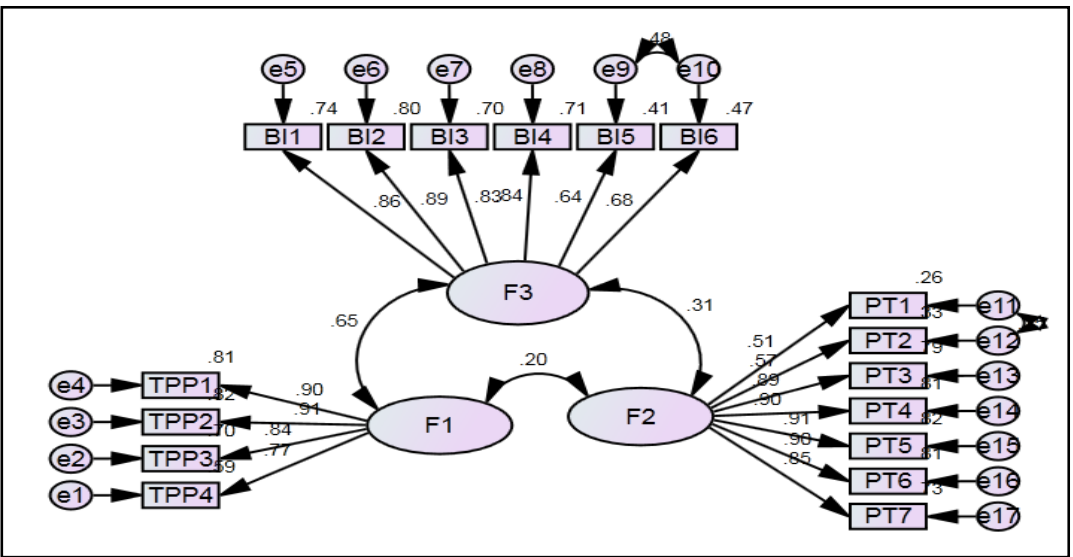

Fig. 6. Model-3 (F1= Teacher preparation programmes; F2 = perceptions of technology integration, and F3= behavioural intention for technology integration)

CFA was performed to test the model fitness and the results are presented in table 12. All the items have excellent loadings $(>0.50)$ and hence there was no need to drop any item from the analysis. The fit-indices for default measurement model-3 indicate poor model fit $\left(\mathrm{X}^{2} / \mathrm{df}=4.62, \mathrm{RMSEA}=.09, \mathrm{IFI}=.85, \mathrm{TLI}=.84, \mathrm{CFI}=.85\right)$, and by following the modification indices excellent model fit was achieved, as the revised model fit results show $\left(\mathrm{X}^{2} / \mathrm{df}=1.50, \mathrm{RMSEA}=.05, \mathrm{IFI}=.98, \mathrm{TLI}=.97, \mathrm{CFI}=.98\right)$.

Table 12.

Model-3 Fit Summary

\begin{tabular}{|l|c|c|c|c|c|}
\hline \multicolumn{1}{|c|}{ Measurement Models (Model-3) } & $\mathbf{X}^{2} / \mathbf{d f}$ & RMSEA & IFI & TLI & CFI \\
\hline Original Model & 4.62 & .09 & .851 & .844 & .851 \\
\hline Revised Model & 1.50 & .05 & .977 & .972 & .977 \\
\hline Cut-off Criteria [ $\underline{50}]$ & $<3.00$ & $<.08$ & $\geq .95$ & $\geq .95$ & $\geq .95$ \\
\hline
\end{tabular}




\section{Discussion}

Technical and vocational education entirely depends upon the equipment, and the entire implementation process is based on such procedures and methods that require knowledge and expertise of stakeholders [52, 53]. Study results demonstrate that every stakeholder has insight into efficient technology education integration. For example, among all other stakeholders, teachers and educational leaders have greater awareness of technology integration. The study results indicate that the willingness and enthusiasm of technology professionals to play an important role in effective integration of technology in the TVEC. The willingness of stakeholders is important because their efforts are pivotal for success and their intensions, experiences, skills, and values are essential to the successful involvement of innovation [54]. There are no differences between instructors and teachers in terms of their perceived concepts of technology utilization in education. However, a traditional, book-based approach was mostly preferred by teachers for low achievers, rather than technology-integrated education. Furthermore, stakeholders' agreement regarding integration of technology education in the curriculum is also correlated with their comfort with the content, students, technology, and teaching generally [55].

Academic professionals and teachers have strong agreement on the fact that technology and technical equipment are essential for both trainers and teachers, hence they should be integral part of the curriculum. The study findings are well supported by the findings of past researchers, such as the study by Maninger and Anderson [56] that showed stakeholder's perception about technology integration in primary education was reasonably positive and high. This study also showed that stakeholders often welcome the abilities of diverse technologies that are implemented to improve the teaching/learning process [57-59].

The study findings reveal that most of the respondents and stakeholders showed a readiness to incorporate technology in education. Past studies concluded that common use of technology in daily life reflects the global need to use technology for worldwide power, as new generation students are more familiar with technology because of its significant role in their jobs [18]. This study also explored significant correlations between stakeholders' perceptions and teacher technology integration, and availability of technology equipment and teacher technology integration. The study findings are well supported by the Davies and West [60] study that explored a significant rise in access to technology, its accessibility, usage, and its incorporation in the educational sector. Numerous past researchers have been focused on the enhancement of learning through use of technology [61]. This study found a small but significant effect of resources or equipment availability and teacher technology integration, and teacher preparation programmes and perception of technology integration.

The results and findings of this study also reveal that the mission, vision, and goals of TVTC have a significant and positive effect on the perceptions of stakeholders regarding technology integration. These findings are in accordance with the study of Li (2007), who also explored that mission, vision, and goals of TVTC significantly affect the perceptions of stakeholders. Means and Olson [62] also suggested that academic professionals should have a clear mission and vision statement first; then they 
should decide about spending and investing in technology integration. Otherwise, all efforts will be directionless.

This study also identified that teacher preparation programmes at university have a significant impact on behavioural intentions for technology integration. These results are similar to previous studies, which revealed that most teachers consider technology as a way to increase self-confidence among students [60]. The results of this study suggest that teacher preparation programs at university have a significant effect in developing behavioural intentions among stakeholders. Furthermore, it is important to foster favourable perceptions of technology education integration among stakeholders in continuing education. Notably, Rogers [18] reported a significant increase in the dealing and behavioural intentions of stakeholders and teachers due to familiarity with digital technologies in everyday activities following professional training and development.

\section{Limitations and Future Recommendations}

This study is limited to the teachers and administrators of TVCs in the United Arab Emirates. A future study to collect research data from other countries is recommended. Moreover, to generalize the results, a future study of fields of education other than technical and vocational would be useful. Furthermore, the researchers were not able to control the environment in which the research was conducted. The responses from the respondents were dependent on the state of technology education during time of the study; hence the findings will be of limited value in the future. Based on the results of this study, it is recommended that TVEC teachers and trainers use integrated technology curricula in their teaching as it is not only to be used in vocational institutes, but also in schools, colleges and universities, which might facilitate the process of teaching and learning.

\section{Conclusion}

The UAE government, like other Gulf countries, is integrating technology education into the general educational curriculum. This study is an effort to draw attention to the significance and advantages of technology integration in technical and vocational education, as technology education is not fully incorporated in the TVE curriculum. Moreover, the study found significant relationships among teachers' technology integration, teacher training programmes, accessibility to technical resources/equipment, and the mission and vision of technical and vocational institutes. Therefore, this study highlights the need for a clear vision and mission and effective teacher training programmes for successful implementation and integration of technology in education. 


\section{Policy Implications}

This study systematically investigated the knowledge of educational stakeholders regarding the integration of technology into the post-secondary curriculum. This investigation will be a significant contribution to existing literature. Moreover, stakeholders' perceptions about technology education integration are shown to justify the UAE's national policies, which consider TVE a critical element for future development, plans, and strategies. This study showed that the current weaknesses in TVE implementation and professional development should be considered to influence the beliefs, behaviours, and attitudes of teachers and provide them with the skills and knowledge to more effectively integrate technology in education.

\section{References}

[1] Unevoc.unesco. What is TVET? 2006 [cited 2020 April 2]; Available from: https://unevoc.unesco.org/home/more\%20about\%20What\%20is\%20TVET.

[2] NESCO, Proposal for The Revision of The 2001 Revised Recommendation Concerning Technical And Vocational Education. 2015, UNESCO Paris.

[3] The-Editors-of-Encyclopaedia-Britannica. Technical education. 1998 [cited 2020 April 02]; Available from: https://www.britannica.com/topic/technical-education.

[4] Colley, H., et al., Learning as becoming in vocational education and training: class, gender and the role of vocational habitus. Journal of vocational education and training, 2003. 55(4): p. 471-498. https://doi.org/10.1080/13636820300200240

[5] Hanushek, E.A., et al., General education, vocational education, and labor-market outcomes over the lifecycle. Journal of human resources, 2017. 52(1): p. 48-87. https://doi. org/10.3368/jhr.52.1.0415-7074r

[6] Wolf, A., Review of vocational education. London: DfE, 2011.

[7] Finch, C.R. and J.R. Crunkilton, Curriculum development in vocational and technical education. planning, content, and implementation. 1999: ERIC.

[8] Knoll, M., The Project Method: Its Vocational Education Origin and International Development. Journal of Industrial Teacher Education, 1997. 34(3): p. 59-80.

[9] Hermans, R., et al., The impact of primary school teachers' educational beliefs on the classroom use of computers. Computers \& education, 2008. 51(4): p. 1499-1509. https:// doi.org/10.1016/j.compedu.2008.02.001

[10] Papadakis, S., Zaranis, N., and M. Kalogiannakis, Parental involvement and attitudes towards young Greek children's mobile usage. International Journal of Child-Computer Interaction, 22, 100144, 2019. https://doi.org/10.1016/j.ijcci.2019.100144

[11] Thomas, M.O. and C. Vela, Computers in the Primary Classroom: Barriers to Effective Use. International Group for the Psychology of Mathematics Education, 2003. 4: p. 347354.

[12] Rauner, F. and R. Maclean, Handbook of technical and vocational education and training research. Vol. 49. 2008: Springer.

[13] Parnell, D., Making It Fly. Lessons in Applied Learning. Techniques: Making Education and Career Connections, 1999. 74(2): p. 18-21.

[14] Goel, V.P. and P. Vijay, Technical and vocational education and training (TVET) system in India for sustainable development. Bonn, UNEVOC, 2011.

[15] Friedman, T.L., The world is flat: A brief history of the twenty-first century. 2005: Macmillan. 
[16] Silverberg, M., et al., National Assessment of Vocational Education. Final Report to Congress. US Department of Education, 2004.

[17] Murata, S. and S. Stern, Technology Education in Japan. Journal of Technology Education, 1993. 5(1): p. 29-37.

[18] Rogers, R.K., Computer anxiety and innovativeness as predictors of technology integration. 2007, Texas Tech University.

[19] Fath-Allah, M., Teaching technology in general schools. 2006, Riyadh, Saudi Arabia: Alsomaie House.

[20] Lillis, T., et al., Working with academic literacies: Case studies towards transformative practice. 2016: The WAC Clearinghouse/Parlor Press.

[21] Williams, P.J., Technological literacy: A multliteracies approach for democracy. International Journal of Technology and Design Education, 2009. 19(3): p. 237-254. https://doi. org/10.1007/s10798-007-9046-0

[22] Bahgat, G., Education in the Gulf monarchies: Retrospect and prospect. International review of education, 1999. 45(2): p. 127-136.

[23] Phillips, D., Learning from elsewhere in education: some perennial problems revisited with reference to British interest in Germany. Comparative Education, 2000. 36(3): p. 297-307. https://doi.org/10.1080/713656617

[24] Wiseman, A.W. and E. Anderson, ICT-integrated education and national innovation systems in the Gulf Cooperation Council (GCC) countries. Computers \& Education, 2012. 59(2): p. 607-618. https://doi.org/10.1016/j.compedu.2012.02.006

[25] Hopken, G., Technology Teacher Education in Germany. International Technology Teacher Education, 2008. 19: p. 69.

[26] Al-Zahrani, A., The Place of Technology Integration in Saudi Pre-Service Teacher Education: Matching Policy with Practice. Turkish Online Journal of Educational TechnologyTOJET, 2015. 14(1): p. 151-162.

[27] Papadakis S., \& Kalogiannakis, M. (2018). Using Gamification for Supporting an Introductory Programming Course. The Case of ClassCraft in a Secondary Education Classroom. In A. Brooks, E. Brooks, N. Vidakis (Eds), Interactivity, Game Creation, Design, Learning, and Innovation. ArtsIT 2017, DLI 2017. Lecture Notes of the Institute for Computer Sciences, Social Informatics and Telecommunications Engineering, vol 229, (pp. 366-375), Switzerland, Cham: Springer. https://doi.org/10.1007/978-3-319-76908-0 35

[28] Harter, C., Making Connections: Integrating Computer Applications with the Academic Core. Techniques: Connecting Education and Careers (J1), 2011. 86(7): p. 40-43.

[29] Johnson, D.W., Cooperative Learning: Increasing College Faculty Instructional Productivity. ASHE-ERIC Higher Education Report No. 4, 1991. 1991: ERIC.

[30] Foster, J., et al., CTE's Focus on Continuous Improvement. Techniques: Connecting Education and Careers (J1), 2011. 86(4): p. 28-31.

[31] Somyürek, S., Gaining the attention of generation Z in learning process: Augmented reality. Educational Technology Theory and Practice, 2014. 4(1): p. 63-80.

[32] Doğan, İ., Examination of the technology leadership self-efficacy perceptions of educational managers in terms of the self-efficacy perceptions of information technologies (Malatya province case). Participatory Educational Research, 2018. 5(2): p. 51-66. https://doi. org/10.17275/per.18.9.5.2

[33] Al Hammadi, A.R.J. and S.S. Mohiuddin, Growing Trends of the Vocational Education in UAE. 2017

[34] Achieve, Ready or not. 2004, Washington, DC: American Diploma Project, Achieve.

[35] Kazis, R. and S. Goldberger, The role of employers: The integration of work-based learning. Education through occupations in American high schools, Volume 2 (pp. 171-190). 1995, New York: Teachers College Press.

[36] Education-World-Forum, UK Technical and Vocational Skills System. 2018.

[37] Patrick, D., Establishing the Readiness Project. 2007, THE COMMONWEALTH OF MASSACHUSE. 
[38] British-Council, The UK Skills System-An Introduction. 2017.

[39] Abdulla, F. and N. Ridge. Where are all the men? Gender, participation and higher education in the United Arab Emirates. in Towards an Arab higher educational space: International challenges and societal responsibilities: Proceedings of the Arab Regional Conference on Higher Education, edited by Bechir Lamine. 2011. https://doi.org/10.14257/astl.20 $\underline{13.36 .01}$

[40] Heritage-Foundation. United Arab Emirates. 2020 [cited 2020 April 3]; Available from: https://www.heritage.org/index/pdf/2020/countries/unitedarabemirates.pdf.

[41] Baldauf, B., T. Hogarth, and M.d. Hoyos, Going global?UK FE/TVET - opportunities in the international market. 2008

[42] National-Qualifications-Authority-UAE. TVET in the UAE. 2019 [cited 2020 April 2020]; Available from: https://www.nqa.gov.ae/EN/Pages/VET/VETUAE.aspx.

[43] Hammadi, A.R.J.A., An Overview - Indicators of the Vocational Education Sector in UAE. International Journal of Scientific \& Engineering Research, 2016. 7(6): p. 995-1001.

[44] UAE's-Governmental-Portal. Technical and Vocational Education in the UAE. 2019 [cited 2020 April 3, 2020]; Available from: https://u.ae/en/information-andservices/education/technical-and-vocational-education.

[45] Knowledge-and-Human-Development-Authority-Dubai. Technical and Vocational Education and Training (TVET). 2020 [cited 2020 April 4, 2020]; Available from: https://www.khda.gov.ae/en/tvet.

[46] Raven, J., Emiratizing the education sector in the UAE: Contextualization and challenges. Education, Business and Society: Contemporary Middle Eastern Issues, 2011. https://doi. org/10.1108/17537981111143864

[47] Qualification-and-Awards-in-Dubai, What are Accredited TVET Qualifications. 2020.

[48] White, D.B., An assessment of the level of school law knowledge of South Carolina school principals and the implications for litigation and social justice. 2012, University of South Carolina.

[49] Henseler, J., C.M. Ringle, and M. Sarstedt, A new criterion for assessing discriminant validity in variance-based structural equation modeling. Journal of the academy of marketing science, 2015. 43(1): p. 115-135. https://doi.org/10.1007/s11747-014-0403-8

[50] Hu, L.t. and P.M. Bentler, Cutoff criteria for fit indexes in covariance structure analysis: Conventional criteria versus new alternatives. Structural equation modeling: a multidisciplinary journal, 1999. 6(1): p. 1-55. https://doi.org/10.1080/10705519909540118

[51] Hair, J.F., et al., Multivariate data analysis. Vol. 5. 1998: Prentice hall Upper Saddle River, NJ.

[52] Tremblay, M.S., et al., Global matrix 2.0: report card grades on the physical activity of children and youth comparing 38 countries. Journal of physical activity and health, 2016. 13(s2): p. S343-S366. https://doi.org/10.1123/jpah.2016-0594

[53] Vardhan, J. and G. Shahul Hameed, Transition of higher education system in UAE-an internationalisation perspective. International Journal of Arab Culture, Management and Sustainable Development, 2012. 2(4): p. 292-308. https://doi.org/10.1504/ijacmsd.2012.0 $\underline{53393}$

[54] Surry, D.W., D.C. Ensminger, and M. Haab, A model for integrating instructional technology into higher education. British journal of educational technology, 2005. 36(2): p. 327329. https://doi.org/10.1111/j.1467-8535.2005.00461.x

[55] Banathy, B.H. and P.M. Jenlink, Systems inquiry and its application in education, in Handbook of research on educational communications and technology. 2013, Routledge. p. 49-69.

[56] Maninger, R.M. and S.E. Anderson, Beyond skills: Evaluating the impact of educational technology instruction. ESCIENTIAE RERUM, 2007: p. 122.

[57] Adedoja, G., Pre-Service Teachers' Challenges and Attitude toward the Flipped Classroom. African Educational Research Journal, 2016. 4(1): p. 13-18. 
[58] Papadakis, S. (2018). Evaluating pre-service teachers' acceptance of mobile devices with regards to their age and gender: a case study in Greece. International Journal of Mobile Learning and Organisation, 12(4), 336-352. https://doi.org/10.1504/ijmlo.2018.10013372

[59] Papadakis, St., and Kalogiannakis, M. (2019). Evaluating a course for teaching introductory programming with Scratch to pre-service kindergarten teachers. Int. J. Technology Enhanced Learning, 11(3), 231-246. https://doi.org/10.1504/ijtel.2019.10020447

[60] Davies, R.S. and R.E. West, Technology integration in schools, in Handbook of research on educational communications and technology. 2014, Springer: New York, NY. p. 841853. https://doi.org/10.1007/978-1-4614-3185-5 68

[61] Li, Q., Student and teacher views about technology: A tale of two cities? Journal of research on Technology in Education, 2007. 39(4): p. 377-397. https://doi.org/10.1080/153 91523.2007.10782488

[62] Means, B. and K. Olson, Technology and education reform: Washington. DC: US Department of Education, 1997.

\section{Authors}

Amjad K. Owais is an instructor of English language at Al Ain University, UAE. He is currently the supervisor of the English Language Center in Abu Dhabi campus. His research interests lie in the areas of applied linguistics, global Englishes, new world order of English, and psycholinguistics.

Suzan Al Abidi is an assistant professor in the College of Education at Al Ain University, UAE. She holds $\mathrm{PhD}$. in education/curriculum and instruction. her research interest is in integration the content knowledge and pedagogical knowledge in health and science education to promote curriculum development. suzan.alabidi@aau.ac.ae

Zaydoon M. Hatamleh is a senior ICT instructor in the College of Engineering at Al Ain University, UAE. He is pursuing his PhD studies in Information Systems at the Universiti Teknologi Malaysia (UTM), Malaysia. His research interests are Big Data Analytics and Data Mining. zaydoon.Hatamleh@aau.ac.ae

Elham T. Hussein is an associate professor of English literature at Al Ain University. Professor Hussein is a graduate of Purdue University. She has taught literature courses in a number of countries including Jordan, KSA and UAE. Her research focuses on postcolonial literature, cultural studies and memoirs. elhamrambadwi@yahoo.com

Article submitted 2020-02-17. Resubmitted 2020-04-04. Final acceptance 2020-04-06. Final version published as submitted by the authors. 


\section{Appendix I}

Table 13. Validity of Questionnaire's items

\begin{tabular}{|c|c|c|}
\hline \multicolumn{3}{|c|}{ Teacher Preparation Programs (TPP) } \\
\hline$S N$ & Term & Validity \\
\hline 1 & TPP1 & 0.90 \\
\hline 2 & TPP2 & 0.91 \\
\hline 3 & TPP3 & 0.84 \\
\hline 4 & TPP4 & 0.77 \\
\hline \multicolumn{3}{|c|}{ Perceptions of technology integration (PT) } \\
\hline$S N$ & Term & Validity \\
\hline 1 & PT1 & 0.51 \\
\hline 2 & PT2 & 0.57 \\
\hline 3 & PT3 & 0.89 \\
\hline 4 & PT4 & 0.90 \\
\hline 5 & PT5 & 0.91 \\
\hline 6 & PT6 & 0.90 \\
\hline 7 & PT7 & 0.85 \\
\hline \multicolumn{3}{|c|}{ Behavioural intention for technology integration (BI) } \\
\hline$S N$ & Term & Validity \\
\hline 1 & BI1 & 0.86 \\
\hline 2 & $\mathrm{BI} 2$ & 0.89 \\
\hline 3 & $\mathrm{BI} 3$ & 0.83 \\
\hline 4 & BI4 & 0.84 \\
\hline 5 & BI5 & 0.64 \\
\hline 6 & BI6 & 0.68 \\
\hline \multicolumn{3}{|c|}{ Mission, vision, values and goals (MVG) } \\
\hline$S N$ & Term & Validity \\
\hline 1 & MVG1 & 0.79 \\
\hline 2 & MVG2 & 0.66 \\
\hline 3 & MVG3 & 0.67 \\
\hline 4 & MVG4 & 0.75 \\
\hline 5 & MVG5 & 0.69 \\
\hline \multicolumn{3}{|c|}{ Stakeholders' perceptions (SP) } \\
\hline$S \boldsymbol{S r} \#$ & Term & Validity \\
\hline 1 & SP1 & 0.77 \\
\hline 2 & $\mathrm{SP} 2$ & 0.82 \\
\hline 3 & SP3 & 0.75 \\
\hline 4 & SP4 & 0.73 \\
\hline 5 & SP5 & 0.76 \\
\hline 6 & SP6 & 0.82 \\
\hline 7 & SP7 & 0.84 \\
\hline 8 & SP8 & 0.75 \\
\hline 9 & SP9 & 0.75 \\
\hline \multicolumn{3}{|c|}{ Equipment availability (EF) } \\
\hline$S N$ & Term & Validity \\
\hline 1 & EF1 & 0.87 \\
\hline 2 & EF2 & 0.87 \\
\hline
\end{tabular}




\begin{tabular}{|c|c|c|}
\hline 3 & EF3 & 0.84 \\
\hline 4 & EF4 & 0.81 \\
\hline 5 & EF5 & 0.63 \\
\hline 6 & EF6 & 0.71 \\
\hline 7 & EF7 & 0.75 \\
\hline 8 & EF8 & 0.69 \\
\hline 9 & EF9 & 0.81 \\
\hline 10 & EF10 & 0.83 \\
\hline \multicolumn{3}{|c|}{ Teacher Technology Integration (TTI) } \\
\hline$S N$ & Term & Validity \\
\hline 1 & TTI1 & 0.51 \\
\hline 2 & TTI2 & 0.58 \\
\hline 3 & TTI3 & 0.88 \\
\hline 4 & TTI4 & 0.90 \\
\hline 5 & TTI5 & 0.91 \\
\hline 6 & TTI6 & 0.89 \\
\hline 7 & TTI7 & 0.85 \\
\hline 8 & TTI8 & 0.81 \\
\hline 9 & TTI9 & 0.83 \\
\hline 10 & TTI10 & 0.84 \\
\hline \multicolumn{3}{|c|}{ Stakeholders' perceptions for Technology } \\
\hline$S N$ & Term & Validity \\
\hline 1 & SP1 & 0.87 \\
\hline 2 & SP2 & 0.90 \\
\hline 3 & SP3 & 0.83 \\
\hline 4 & SP4 & 0.84 \\
\hline 5 & SP5 & 0.54 \\
\hline 6 & SP6 & 0.69 \\
\hline 7 & SP7 & 0.69 \\
\hline
\end{tabular}

\section{Appendix II}

Table 14.

The Questionnaire's items

\begin{tabular}{|c|c|c|c|c|c|c|}
\hline Sr. & Questions & \multicolumn{5}{|c|}{ Response } \\
\hline 1 & $\begin{array}{l}\text { The technological revolution requires gov- } \\
\text { ernments to review curricula }\end{array}$ & $\begin{array}{l}\text { Strongly } \\
\text { Disagree }\end{array}$ & Disagree & Neutral & Agree & $\begin{array}{l}\text { Strongly } \\
\text { Agree }\end{array}$ \\
\hline 2 & $\begin{array}{l}\text { The technological revolution will require } \\
\text { colleges and institutes to develop students' } \\
\text { technological literacy }\end{array}$ & $\begin{array}{l}\text { Strongly } \\
\text { Disagree }\end{array}$ & Disagree & Neutral & Agree & $\begin{array}{l}\text { Strongly } \\
\text { Agree }\end{array}$ \\
\hline 3 & $\begin{array}{l}\text { Teaching technology courses in the colleges } \\
\text { and institutes sure will contribute in devel- } \\
\text { oping student's proficiencies to solve techno- } \\
\text { logical problems }\end{array}$ & $\begin{array}{l}\text { Strongly } \\
\text { Disagree }\end{array}$ & Disc & Neutral & Agree & $\begin{array}{l}\text { Strongly } \\
\text { Agree }\end{array}$ \\
\hline 4 & $\begin{array}{l}\text { Students need knowledge that helps in } \\
\text { keeping up and understanding of technologi- } \\
\text { cal changes. }\end{array}$ & $\begin{array}{l}\text { Strongly } \\
\text { Disagree }\end{array}$ & Disagree & Neutral & Agree & $\begin{array}{l}\text { Strongly } \\
\text { Agree }\end{array}$ \\
\hline 5 & $\begin{array}{l}\text { Developing a wide range of knowledge and } \\
\text { technological skills is a must for students }\end{array}$ & $\begin{array}{l}\text { Strongly } \\
\text { Disagree }\end{array}$ & Disagree & Neutral & Agree & $\begin{array}{l}\text { Strongly } \\
\text { Agree }\end{array}$ \\
\hline
\end{tabular}




\begin{tabular}{|c|c|c|c|c|c|c|}
\hline 6 & $\begin{array}{l}\text { colleges and institutes students need to } \\
\text { develop an appreciation of the importance of } \\
\text { technology to development of the country }\end{array}$ & $\begin{array}{l}\text { Strongly } \\
\text { Disagree }\end{array}$ & Disagree & Neutral & Agree & $\begin{array}{l}\text { Strongly } \\
\text { Agree }\end{array}$ \\
\hline 7 & $\begin{array}{l}\text { colleges and institutes students would bene- } \\
\text { fit from their learning of designing techno- } \\
\text { logical products }\end{array}$ & $\begin{array}{l}\text { Strongly } \\
\text { Disagree }\end{array}$ & Disagree & Neutral & Agree & $\begin{array}{l}\text { Strongly } \\
\text { Agree }\end{array}$ \\
\hline 8 & $\begin{array}{l}\text { colleges and institutes students' need an } \\
\text { awareness and understanding of the interac- } \\
\text { tion between technology and society }\end{array}$ & $\begin{array}{l}\text { Strongly } \\
\text { Disagree }\end{array}$ & Disagree & Neutral & Agree & $\begin{array}{l}\text { Strongly } \\
\text { Agree }\end{array}$ \\
\hline 9 & $\begin{array}{l}\text { Students must be creative and smart thinkers } \\
\text { in their colleges and institutes }\end{array}$ & $\begin{array}{l}\text { Strongly } \\
\text { Disagree }\end{array}$ & Disagree & Neutral & Agree & $\begin{array}{l}\text { Strongly } \\
\text { Agree }\end{array}$ \\
\hline 10 & $\begin{array}{l}\text { Hands on and practical activity contribute in } \\
\text { making learning easier and fun }\end{array}$ & $\begin{array}{l}\text { Strongly } \\
\text { Disagree }\end{array}$ & Disagree & Neutral & Agree & $\begin{array}{l}\text { Strongly } \\
\text { Agree }\end{array}$ \\
\hline 11 & $\begin{array}{l}\text { Technology is very important for students; } \\
\text { without it they feel powerless }\end{array}$ & $\begin{array}{l}\text { Strongly } \\
\text { Disagree }\end{array}$ & Disagree & Neutral & Agree & $\begin{array}{l}\text { Strongly } \\
\text { Agree }\end{array}$ \\
\hline 12 & $\begin{array}{l}\text { Current primary curricula prepare students to } \\
\text { be creative and inventive }\end{array}$ & $\begin{array}{l}\text { Strongly } \\
\text { Disagree }\end{array}$ & Disagree & Neutral & Agree & $\begin{array}{l}\text { Strongly } \\
\text { Agree }\end{array}$ \\
\hline 13 & $\begin{array}{l}\text { The training curriculum in the institution is } \\
\text { designed according to standards for the } \\
\text { integration of technology in training }\end{array}$ & $\begin{array}{l}\text { Strongly } \\
\text { Disagree }\end{array}$ & Disagree & Neutral & Agree & $\begin{array}{l}\text { Strongly } \\
\text { Agree }\end{array}$ \\
\hline 14 & $\begin{array}{l}\text { Current developed curricula for colleges and } \\
\text { institutes include a good number of techno- } \\
\text { logical topics }\end{array}$ & $\begin{array}{l}\text { Strongly } \\
\text { Disagree }\end{array}$ & Disagree & Neutral & Agree & $\begin{array}{l}\text { Strongly } \\
\text { Agree }\end{array}$ \\
\hline 15 & $\begin{array}{l}\text { Current curricula help students to use tech- } \\
\text { nology when they enter the labour market } \\
\text { after graduation }\end{array}$ & $\begin{array}{l}\text { Strongly } \\
\text { Disagree }\end{array}$ & Disagree & Neutral & Agree & $\begin{array}{l}\text { Strongly } \\
\text { Agree }\end{array}$ \\
\hline 16 & $\begin{array}{l}\text { Trainers have good knowledge of the tech- } \\
\text { nology that can be used in training }\end{array}$ & $\begin{array}{l}\text { Strongly } \\
\text { Disagree }\end{array}$ & Disagree & Neutral & Agree & $\begin{array}{l}\text { Strongly } \\
\text { Agree }\end{array}$ \\
\hline 17 & $\begin{array}{l}\text { Trainers understand the importance of } \\
\text { teaching technology in colleges and insti- } \\
\text { tutes to produce technical generation }\end{array}$ & $\begin{array}{l}\text { Strongly } \\
\text { Disagree }\end{array}$ & Disagree & Neutral & Agree & $\begin{array}{l}\text { Strongly } \\
\text { Agree }\end{array}$ \\
\hline 18 & $\begin{array}{l}\text { Trainers understand that the use of technolo- } \\
\text { gy tools and concepts facilitate the learning } \\
\text { process }\end{array}$ & $\begin{array}{l}\text { Strongly } \\
\text { Disagree }\end{array}$ & Disagree & Neutral & Agree & $\begin{array}{l}\text { Strongly } \\
\text { Agree }\end{array}$ \\
\hline 19 & $\begin{array}{l}\text { I teach and help my students to plan and } \\
\text { produce simple technical products }\end{array}$ & $\begin{array}{l}\text { Strongly } \\
\text { Disagree }\end{array}$ & Disagree & Neutral & Agree & $\begin{array}{l}\text { Strongly } \\
\text { Agree }\end{array}$ \\
\hline 20 & $\begin{array}{l}\text { I find in myself the ability and the compe- } \\
\text { tence to teach technology in colleges and } \\
\text { institutes education }\end{array}$ & $\begin{array}{l}\text { Strongly } \\
\text { Disagree }\end{array}$ & Disagree & Neutral & Agree & $\begin{array}{l}\text { Strongly } \\
\text { Agree }\end{array}$ \\
\hline 21 & $\begin{array}{l}\text { Instructors from different disciplines can } \\
\text { teach technology education }\end{array}$ & $\begin{array}{l}\text { Strongly } \\
\text { Disagree }\end{array}$ & Disagree & Neutral & Agree & $\begin{array}{l}\text { Strongly } \\
\text { Agree }\end{array}$ \\
\hline 22 & $\begin{array}{l}\text { Trainers understand that using technology } \\
\text { tools and concepts helps learners learn }\end{array}$ & \begin{tabular}{|l} 
Strongly \\
Disagree
\end{tabular} & Disagree & Neutral & Agree & $\begin{array}{l}\text { Strongly } \\
\text { Agree }\end{array}$ \\
\hline 23 & $\begin{array}{l}\text { Instructors often discuss technology-related } \\
\text { topics }\end{array}$ & $\begin{array}{l}\text { Strongly } \\
\text { Disagree }\end{array}$ & Disagree & Neutral & Agree & $\begin{array}{l}\text { Strongly } \\
\text { Agree }\end{array}$ \\
\hline 24 & $\begin{array}{l}\text { Current trainers can integrate technology } \\
\text { components with their training curriculum }\end{array}$ & $\begin{array}{l}\text { Strongly } \\
\text { Disagree }\end{array}$ & Disagree & Neutral & Agree & $\begin{array}{l}\text { Strongly } \\
\text { Agree }\end{array}$ \\
\hline 25 & $\begin{array}{l}\text { I see myself as a qualified instructor to teach } \\
\text { technology in institutions. }\end{array}$ & $\begin{array}{l}\text { Strongly } \\
\text { Disagree }\end{array}$ & Disagree & Neutral & Agree & $\begin{array}{l}\text { Strongly } \\
\text { Agree }\end{array}$ \\
\hline
\end{tabular}

Source: (Oganlana, 2010; Cakir, 2012; Ono et al., 2017) 